\title{
Pelaksanaan fungsi pokok humas pemerintah pada lembaga pemerintah
}

\author{
FX. Ari Agung Prastowo \\ Universitas Padjadjaran, Bandung, Indonesia
}

\begin{abstract}
ABSTRAK
Fungsi humas dalam sebuah lembaga dapat menjadi sarana untuk mengoptimalkan pelayanan publik khususnya dalam penyebaran informasi. Sehingga jika dilakukan secara optimal, fungsi humas dapat meningkatkan kinerja lembaga juga kepercayaan publik. Kendala dalam pelaksanaan fungsi humas pemerintah harus segera diminimalisir, agar tidak berakibat pada turunnya kepercayaan masyarakat kepada kinerja pemerintah yang berbasis pelayanan. Untuk itu, penelitian ini dilakukan untuk mengetahui: pelaksanaan fungsi pokok humas pemerintah pada lembaga pemerintah. Metode penelitian ini adalah deskriptif dengan analisis data kualitatif. Subjek penelitian ini adalah pejabat humas pemerintah yang berasal dari beberapa lembaga diantaranya: (1) Kementerian Pendidikan Nasional; (2) Kementerian Komunikasi dan Informatika; (3) Kementerian Pendayagunaan Aparatur Negara dan Reformasi Birokrasi; (4) Kementerian Koordinator Politik, Hukum dan Keamanan. Data yang dikumpulkan dalam penelitian ini adalah data primer diperoleh dari hasil pengamatan dan wawancara mendalam. Hasil penelitian ini adalah terdapat tahapan yang dilakukan lembaga pemerintah dalam pelaksanaan fungsi humas sebagai saluran penyebar informasi. Informasi yang disampaikan harus valid dan jelas serta menggunakan media yang tepat. Peneliti merekomendasikan agar lembaga Pemerintah mengoptimalkan media online sebagai sarana untuk menyebarkan informasi pada publik. Begitu pula dengan pelaksanaan fungsi pelayanan publik. Humas pemerintah sudah hakekatnya untuk menjalankan fungsi ini, maka sudah seharusnya lembaga Pemerintah bisa memberikan pelayanan prima pada masyarakat. Hal yang harus diperhatikan oleh praktisi humas dalam pelaksanaan fungsi pokok humas pemerintah sebagai fasilitator komunikasi antara lembaga dan masyarakat adalah dengan menggunakan komunikasi dua arah juga bertindak sebagai negosiator bukan hanya sebagai komunikator.
\end{abstract}

Kata-kata Kunci: Humas; pemerintah; fungsi; media; informasi

\section{Implementation of the principal function of government public relations at government agencies} ABSTRACT

The function of public relations in an institution can be a means to optimize public services, especially in the dissemination of information. If done optimally, the public relations function would be able to improve the performance of institutions as well as increasing public trust. Limitation in the implementation of the Government's public relations function must be immediately removed so that it would be able to maintain public trust. The research was conducted to explore the implementation of the main functions of government public relations in government institutions. The method of research is descriptive with qualitative data analysis. The subjects of this study were Government Public Relations Officers from several institutions (1) Ministry of National Education, (2) Ministry of Communication and Information Technology, (3) Ministry of Administrative and Bureaucratic Reform, (4) The Coordinating Ministry for Politics, Law, and Security. Data collected in this study are primary data obtained from observations and in-depth interviews. The results of this study show that there are some stages undertaken by government agencies in the implementation of the $P R$ function as a channel for disseminating information. The information must be valid and clear by using the right media. It is suggested that government agencies should optimize online media as a means to disseminate information to the public as public service functions. The Government's public relations are essential as a facilitator of communication between institutions and the public by using two-way communication and act as a negotiator rather than merely as a communicator.

Keywords: Public relations; government; function; media; information

Korespondensi: FX. Ari Agung Prastowo, S.Sos., M.I.Kom. Universitas Padjadjaran. Jl. Raya Bandung Sumedang KM.21, Hegarmanah, Kec. Jatinangor, Kabupaten Sumedang, Jawa Barat 45363. Email:ari. humas@unpad.ac.id.

Submitted: September 2019, Accepted: February 2020, Published: August 2020

ISSN: 2528-6927 (printed), ISSN: 2541-3678 (online). Website: http://jurnal.unpad.ac.id/profesi-humas 


\section{PENDAHULUAN}

Fungsi pokok humas terus mengalami perkembangan termasuk pada humas pemerintah. Perkembangan fungsi humas pemerintah diantaranya adanya dinamika yang muncul karena terjadi peralihan dari era orde baru menuju reformasi. Dampak dari perubahan sistem pemerintahan tersebut dirasakan oleh masyarakat yakni dengan banyak terdapat informasi yang disuguhkan oleh berbagai media bahkan hingga saat ini bukan hanya media konvensional yang menjadi sumber informasi publik namun perkembangan sangat pesat terjadi pada media online.

Fenomena ini merupakan tantangan bagi praktisi humas pemerintah untuk mengelola informasi yang disebarkan melalui media agar penyebaran informasi tersebut dapat mendukung upaya pembentukan opini publik yang positif juga berdampak pada naiknya kepuasan publik terhadap keterbukaan informasi lembaga Pemerintah.

Fungsi pokok humas pemerintah diantaranya adalah: (1) Turut serta menjaga kebijakan Pemerintah; (2) Menyebarkan informasi mengenai kebijakan dan program pemerintah dan melakukan pelayanan pada publik; (3) Menjembatani kepentingan lembaga dan publiknya melalui menampung aspirasi dan memperhatikan keinginan publik; dan (4)
Membentuk iklim positif di sekitar lembaga dan publiknya untuk stabilitas politik juga keamanan nasional (Ruslan, 2016).

Menambahkan fungsi pokok humas pemerintah di atas, bahwa humas pemerintah melakukan publikasi dan lebih menekankan pada pelayanan publik dan meningkatkan pelayanan umum bagi masyarakat (Rahman \& Sjoraida, 2017).

Fungsi humas memiliki arti penting. Setiap lembaga pemerintah harus menyadari bahwa fungsi humas pemerintah sangat penting karena dapat berdampak positif bagi kinerja lembaga maupun kehidupan masyarakat (Waymer, 2013). Sesungguhnya kesadaran akan arti penting public relations untuk lembaga pemerintah sudah sejak lama dimiliki pemimpin pemerintahan di Indonesia. Buktinya adalah dengan adanya departemen penerangan sebagai salah satu departemen yang fungsinya antara lain sebagai humas pemerintah. Departemen penerangan melaksanakan fungsi komunikasi dengan mengkomunikasikan produk ataupun kebijakan yang dikeluarkan oleh pemerintah.

Ada beberapa hal yang melatarbelakangi perkembangan humas pemerintah, diantaranya: (1) Sisi pentingnya humas bagi pemerintah dan (2) Hambatan-hambatan yang dihadapi oleh pemerintah. Dua sisi ini pada akhirnya mengakibatkan humas pemerintah diberi tugas, wewenang dan dibiayai dari berbagai macam 
cara.

Namun demikian, realitasnya ada beberapa lembaga pemerintah terkendala dalam menerapkan fungsi humas. Salah satu penyebabnya adalah posisi humas pemerintah yang masih di bawah bagian lain belum menjadi koalisi dominan artinya adalah Humas pemerintah belum mendapatkan kepercayaan untuk berperan serta dalam merumuskan kebijakan pemerintah. Kebanyakan humas pemerintah diarahkan untuk hubungan dengan media, masalah umum, dokumentasi dan publikasi. Kegiatan-kegiatan yang biasanya ditangani oleh humas dalam rangka mensosialisasikan kebijakan pemerintah ialah mengadakan konferensi pers, membuat press release dan menyebarkannya pada media, pameran-pameran, mengorganisisr pertemuan dengan masyarakat, penerangan melalui berbagai media komunikasi bagi masyarakat. Kendala lain yang muncul dalam penerapan fungsi humas pemerintah adalah pejabat humas pemerintah dalam melaksanakan tugas menyesuaikan dengan peraturan-peraturan yang di tetapkan oleh pemerintah.

Kendala-kendala yang muncul mengenai implementasi pelaksanaan fungsi humas pemerintah harus segera diminimalisir, agar tidak berakibat pada turunnya kepercayaan masyarakat kepada kinerja pemerintah yang berbasis pelayanan. Dimana masyarakat selalu menuntut cepat dan tepat. Ditambah dengan adanya perkembangan teknologi komunikasi, akan menunjang pelayanan lembaga Pemerintah khususnya dalam menyebarkan informasi dan menjadi fasilitator komunikasi dengan publik.

Media dibutuhkan untuk mendukung implementasi fungsi pokok humas pemerintah. Media memainkan fungsinya, yaitu sebagai pengawas atau kontrol atas segala kebijakan pemerintah atapun peristiwa-peristiwa lainya yang bersifat kontroversial bagi publik. Sesungguhnya fungsi media itu sendiri adalah untuk melayani kepentingan publik, artinya adalah media memiliki tanggungjawab sosial kepada publik, dimana media harus menyampaikan informasi kepada publik yang bersifat terbuka dan jujur serta menyeluruh.

Pada perjalanannya ternyata media bersifat "mendua", maksudnya adalah selain melayani kepentingan publik, media juga melayani kepentingan-kepentingan pemilik, penguasa atapun pengusaha-pengusaha yang dianggap menguntungkan bagi kelangsungan hidup media itu sendiri. Karena kepentingan kelangsunagan hidup media itu sendiri, media kadangkalan memberikan informasi yang bersifat meresahkan bagi masyarakat.

Sesungguhnya dalam sebuah sistem politik sebuah negara, media memiliki fungsi kontrol atas kebijakan pemerintah, sehingga pemerintah selain di awasi oleh partai oposisi 
juga mendapatkan pengawasan dari media. 2016).

Disinilah peran media sebagai "pengawal" kebijakan pemerintah dan kasus-kasus yang muncul dalam pemerintahan dapat diselesaikan sesuai dengan peraturan dan hukum yang berlaku.

Pentingnya mengoptimalkan pelaksanaan fungsi pokok humas pemerintah tidak hanya mencegah penurunan kepercayaan masyarakat terhadap lembaga, namun juga untuk melaksanakan tanggung jawab lembaga pemerintah untuk menginformasikan kebijakan dan program pemerintah. Pelaksanaan fungsi pokok humas dapat menghimpun dukungan publik yang dibutuhkan demi kelancaran program, juga untuk memenuhi ekspektasi publik terhadap kinerja lembaga (Hong, 2013).

Fenomena-fenomana yang digambarkan di atas, membuat peneliti tertarik untuk tahu lebih banyak mengenai pelaksanaan fungsi pokok humas pemerintah pada lembaga pemerintah. Peneliti mengadopsi konsep fungsi pokok humas, yakni: (1) Fungsi pokok humas pemerintah dalam menyebarkan informasi mengenai kebijakan dan program pemerintah; (2) Fungsi pokok humas pemerintah dalam melakukan pelayanan pada publik; dan (3) Fungsi pokok humas pemerintah dalam menjembatani kepentingan lembaga dan publiknya melalui menampung aspirasi dan memperhatikan keinginan publik (Ruslan,
Berdasarkan latar belakang, tujuan penelitian ini adalah untuk mengetahui pelaksanaan fungsi pokok humas pemerintah pada lembaga pemerintah.

\section{METODE PENELITIAN}

Subjek penelitian ini adalah beberapa narasumber diantaranya adalah pejabat humas pemerintah. Pemilihan narasumber pejabat humas pemerintah diperlukan untuk menemukan data apakah pejabat humas pemerintah sebagai individu memahami fungsi dan perannya sebagai pejabat humas. Penulis mengambil data di lembaga Kementrian dan Lembaga Tinggi Negara, diantaranya adalah: (1) Kementerian Pendidikan Nasional yang sedang menangani isu sentral mengenai Ujian Nasional; (2) Kementerian Komunikasi dan Informatika; (3) Kementerian Pendayagunaan Aparatur Negara dan Reformasi Birokrasi; (4) Kementerian Koordinator Politik, Hukum dan Keamanan.

Objek penelitian terkait dengan pelaksanaan fungsi pokok humas pemerintah pada lembaga pemerintah dan penulis mengambil beberapa contoh pelaksanaan fungsi pokok humas pemerintah. Ketertarikan penulis ditunjang dengan data awal yang penulis dapatkan dari bacaan-bacaan serta pengamatan penulis terkait perkembangan humas pemerintah. Pada 
dasawarsa terakhir ini humas pemerintah sangat disorot fungsi dan perannya dalam mendukung kebijakan pemerintah yang berupaya untuk mengatur kondisi negara dan menyejahterakan masyarakat.

Metode penelitian ini menggunakan metode deskriptif dengan analisis data kualitatif. Melalui metode ini peneliti menggambarkan pelaksanaan fungsi pokok humas pemerintah pada lembaga pemerintah. Penelitian kualitatif mengutamakan pandangan naturalistik dan memandang objek penelitian secara manusiawi. Pemilihan jenis kualitatif oleh penulis, dikarenakan penulis ingin mendapatkan data secara menyeluruh dan mendalam mengenai humas pemerintah.

Data yang dikumpulkan dalam penelitian ini ada dua jenis yaitu primer dan sekunder, data primer diperoleh dari hasil pengamatan dan wawancara mendalam. Data wawancara ini merupakan data utama dalam penelitian ini, sedangkan data sekunder adalah data dari sumber lain yang mendukung penelitian ini, misalnya studi pustaka, dokumentasi dan referensi lainnya, yang akan memperkaya data. Teknik pengumpulan data dilakukan melalui observasi dan wawancara.

Flow analysis model digunakan sebagai teknik analisis data dalam penelitian ini, yakni terdiri dari tiga alur kegiatan yang terjadi secara bersamaan yaitu: 1) Reduksi data; 2) Penyajian data; dan 3) Penarikan kesimpulan. Hal ini seperti yang dijelaskan (Miles, Huberman, \& Saldana, 2014).

\section{HASIL DAN PEMBAHASAN}

Humas pemerintah menjalankan salah satu fungsi pokoknya yakni dengan menyebarkan informasi mengenai kebijakan dan program Pemerintah melalui menjaga aliran informasi yang efektif. Dengan upaya tersebut, lembaga pemerintah dapat mengkomunikasikan informasi mengenai kebijakan dengan baik sehingga dapat diterima oleh masyarakat pada akhirnya masyarakat akan mendukung berbagai kebijakan dan program yang dibuat oleh Pemerintah.

Sebagai garda terdepan dalam instansi pemerintahan, humas pemerintah harus menguasai aliran informasi yang sedang berkembang di instansinya. Bahkan tidak menutup kemungkinan humas pemerintah harus lebih proaktif mencari informasi baik yang berada di dalam organisasi maupun apa yang berkembang di publik. Hal ini seperti yang dijelaskan oleh Muhadjir selaku Kepala Pusat Informasi dan Humas Kementerian Pendidikan Nasional:

“...Fungsi yang kedua agen informasi, kalau gak siap informasi ya, bukan humas. Humas tidak harus membakukan dirinya untuk formal, penyuaraan di media, humas mengemas informasi untuk pimpinan. Sekiranya pimpinan tidak hadir baru humas tampil, tentunya informasi harus valid dan 
kredibel".

Berdasarkan pernyataan di atas dapat diketahui bahwa dalam menjalankan fungsinya, humas pemerintah harus menguasai informasi agar dapat memberikan konten informasi yang valid pada publik. Selain menguasasi kemampuan untuk mengemas konten dengan valid, humas pemerintah juga harus mampu menguasai teknis penyebaran informasi yang dimulai dari fact finding atau pencarian data sadalam-dalamnya mengenai sebuah isu terkait dengan kebijkan lembaga.

Secara teknis penyebaran informasi mengenai program atau kebijakan diperoleh dari staff humas yang mencari, menggali sedalam-dalamnya info-info atau kejadiankejadian yang terjadi di deputi lain. Termasuk di dalamnya adalah kegiatan-kegiatan yang sedang di jalankan oleh deputi lain.

Untuk tahap penggalian informasi dapat dilakukan juga melalui monitoring melalui media ataupun dengan pengumpulan data dan fakta melalui penelitian. Monitoring paling sederhana adalah dengan melalui kliping media, dari media humas pemerintah dapat menganilisis peristiwa atau informasi apa saja yang beredar terkait dengan lembaganya. Oleh karena itu, sebagai agen informasi, humas pemerintah harusnya menjalankan fungsi radarnya atau fungsi intelejen. Hal tersebut seperti diungkapkan oleh Gatot Sugiharto selaku Kepala Biro Humas dan Hukum Kementerian PAN:

"Sebagai wadah informasi, yang harus disampaikan kepada masyarakat, jadi humas harus mempunyai punya link ke deputi-deputi, menempatkan orangnya di deputi-deputi dan harus setiap saat berhubungan dan unit-unit ini harus berkomunikasi dengan kami setiap hari, kalau ada informasi apa, ada perubahan apa itu harus segara disampaikan. Katakanlah kedeputian pelayanan publik ada seminar di Kalimantan selatan, ya sekarang staf saya juga ada disana sekarang, nanti kirim berita lewati email".

Sejalan dengan pernyataan di atas, Kepala Pusat Informasi dan Humas Kementerian Pendidikan Nasional menjelaskan bahwa:

“...seorang Humas Pemerintah harus melakukan fact finding atau memberikan informasi berdasarkan fakta pada publik".

Pelaksanaan fungsi pokok humas pemerintah dalam bentuk media monitoring sudah dilakukan dengan tepat. Media monitoring sebaiknya dilakukan secara efektif dalam pelaksanaan fungsi humas pemerintah karena opini dan reaksi masyarakat mengenai sebuah kebijakan atau program yang telah dilaksanakan oleh lembaga dapat diketahui melalui proses monitoring sehingga hasil akhirnya, monitoring dapat dijadikan bahan evaluasi juga kritikan bagi penyelenggaraan program di sebuah lembaga (Kusumawati, 2008). Hal tersebut akan mempengaruhi kualitas informasi yang 
diberikan pada publik kedepannya.

Informasi yang diperoleh humas pemerintah juga tidak diperkenankan dengan dugaandugaan semata, melainkan dengan penelitian sehingga diperoleh data What Happening Now? apa yang sedang terjadi sekarang, apa yang menjadi kebutuhan publik, apa yang sedang diminati oleh publik dan publik menginginkan apa. Dengan data-data yang valid dan berbasis pada fakta maka humas pemerintah dapat menjadi "bank informasi" yang dipercaya oleh publik internal dan eksternal serta dapat memperkaya ataupun memenuhi kebutuhan akan informasi akan publiknya. Informasi yang diberikan pada publik harus berdasarkan fakta sesuai dengan kejadian yang telah terjadi. Hal ini seperti diungkapkan oleh Ivonhe sebagai Kepala Sub Bidang Internal dan Eksternal Kementerian Komunikasi dan Informatika:

"Fungsi humas menurut saya adalah memberitakan suatu informasi apa saja yang sudah dilakukan oleh Kominfo dan mensosialisasikan melalui media”.

Sebagai kelanjutan dari pelaksanaan fungsi pokok humas pemerintah, setelah menghimpun informasi yang valid, humas pemerintah harus mampu membangun hubungan yang positif dengan media. Hal tersebut seperti diungkapkan oleh Kepala Biro Humas dan Hukum Kementerian PAN:

"Humas yang ideal paling tidak harus mempunyai media center, artinya kita harus menyatu dengan rekan-rekan wartawan, saya ini lagi berjuang, media center saya ini kadang di atas kadang di bawah, tapi saya berjuang untuk ada ruangan khusus tersendiri itu karena kita butuh sekali ruang media center".

Informasi yang telah diperoleh humas pemerintah harus segera didistribusikan kembali secara cepat, sehingga nilai-nilai aktual akan sebuah informasi tidak hilang. Dengan jangkauan yang sangat luas dan cepat media massa atau kawan-kawan wartawan dapat dijadikan mitra dari humas pemerintah, karena pada dasarnya hubungan antara humas pemerintah dengan pers adalah hubungan yang saling menguntungkan, dimana untuk media publisitas dan publikasi humas pemerintah memerlukan rekan-rekan pers, demikian sebaliknya untuk memenuhi kebutuhan berita, rekan-rekan pers memerlukan informasi yang jelas dan akurat dari humas pemerintah.

Hubungan antara humas pemerintah dan pers sangat dekat dan saling tergantung satu sama lain. Hal ini seperti diungkapkan oleh Kepala Sub Bidang Internal dan Eksternal Kementerian Komunikasi dan Informatika: "...antara humas dengan media merupakan hubungan simbiosis mutualisme".

Sehingga berdasarkan pernyataan tersebut diketahui bahwa penting bagi seorang humas pemerintah dalam memperhatikan hubungan dengan Wartawan.

Pelaksanaan fungsi pokok humas dalam 
penyebaran informasi yang dilakukan oleh lembaga pemerintah sudah tepat jika menjalin hubungan baik dengan pers. Hal ini senada dengan yang dijelaskan bahwa dampak positif dari menjaga hubungan yang baik dengan media akan meningkatkan kredibilitas lembaga di mata stakeholder dan kompetitor (Saraswati, Romli, \& Nugraha, 2019). Sebanyak 20\% dari aktivitas yang dilakukan oleh humas berhubungan dengan media. Maka penting untuk menjaga hubungan baik dengan media oleh sebuah lembaga agar informasi yang disampaikan pada publik melalui media sesuai dengan kebutuhan lembaga juga msayarakat.

Koalisi yang harmonis antara humas pemerintah dengan pers merupakan langkah yang sangat strategis. Pers mendapatkan berita ataupun informasi yang transparan, masih hangat mengenai lembaga pemerintahan sedangkan bagi lembaga pemerintah, pers dapat memberitakan mengenai kinerja ataupun prestasi lembaga selama hubungan simbiosis mutualisme antara keduanya perlu dibina dan dipelihara secara berkesinambungan, setara dan seimbang, tanpa saling intervensi, non birokratis, proposional dan professional. Untuk itu, humas pemerintah harus membuka diri agar dapat diakses secara luas oleh pers serta selalu mengedepankan nilai-nilai kejujuran ini.

Ketakutan terhadap pers tidak perlu lagi dipelihara karena hal ini justru akan menjadi cambuk bagi lembaga pemerintahan. Pers sendiri merupakan pilar keempat demokrasi yang selalu melaksanakan fungsinya untuk melakukan fungsi kontrol terhadap kebijakan pemerintah. Sebagai pengawas pers jangan dianggap musuh, justru merupakan rekan kerja yang harus disuguhkan informasi-informasi yang terbuka, jujur dan transaparan. Kesinergian antara pemerintah dengan pers, harapanyaa adalah dapat memenuhi kebutuhan informasi masyarakat, mencerahkan masyarakat, memberdayakan masyarakat dan akhirnya menyejahterakan masyarakat.

Dalam melaksanakan fungsi pokoknya, terdapat anggapan jika humas pemerintah identik hanya sebagai juru bicara dari pemerintah, fenomena ini muncul ketika zaman orde baru. Ini di tandai dengan adanya departemen penerangan yang pada masa itu tugasnya hanya menyampaikan kebijakankebijakan yang dihasilkan oleh pemerintah, tanpa menerangkan apa esensi dari kebijakan itu sendiri. Pengalaman menjadi juru penerang dapat digunakan sebagai cikal bakal pelaksanaan fungsi humas. Hal ini seperti diungkapkan oleh Indarto yang menjabat Kepala Bidang Humas Kementerian PAN:

"Saya dulu juru penerang, saya masuk PNS dikursuskan menjadi juru penerang dan motivasi...".

Karena kedinamisan dunia humas, fungsi hanya sebagai juru bicara pemerintah tidak 
tepat lagi. Pergesaran sistem politik yang terjadi di Indonesia "memaksa" humas pemerintah untuk menyesuaikan diri. Kebutuhan informasi masyarakat yang semakin besar harus diimbangi dengan kemampuan menyampaikan informasi itu sendiri, tidak hanya sekedar bagi-bagi informasi yang nantinya justru akan membuat masyarakat menjadi bingung.

Humas pemerintah harus diimbangi dengan rasa tanggung jawab sosial ketika akan menyampaikan informasi, artinya adalah informasi yang di sampaikan jangan menimbulkan keresahan pada masyarakat, melainkan harus bertanggungjawab, mencerminkan kasih sayang, menimbulkan kesejukan dengan informasi yang transparan dan berbicara fakta.

Salah satu informan menyatakan bahwa posisi humas bukan hanya sekedar komunikator, lebih dari itu humas sebuah lembaga menjadi negosiator untuk mencapai tujuan lembaga. Hal ini seperti diungkapkan oleh Kepala Pusat Informasi dan Humas Kementerian Pendidikan Nasional:

"...humas bertindak sebagai negosiator bukan hanya komunikator”.

Selain memiliki fungsi sebagai komunikator dan lebih luasnya sebagai negosiator, humas pemerintah juga memiliki fungsi untuk melayani informasi publik yang dapat memberikan kejelasan pada masyarakat sehingga nantinya tidak ada multitafsir informasi. Hal ini seperti diungkapkan oleh Kepala Pusat Informasi dan Humas Kementerian Pendidikan Nasional: "...dan melayani informasi yang bersifat mencerahkan”..

Adanya anggapan bahwa humas hanya sebagai corong sebuah lembaga. Hal ini seperti diungkapkan oleh Humas Kementerian Pendidikan Nasional:

"Pejabat Humas Kementerian tidak boleh lebih terkenal dari menterinya".

Hal serupa juga diungkapkan Yufita selaku Kepala Bidang Hubungan Antar Lembaga Kementerian PAN, bahwa:

“...Humas itu pentinglah, kalo gak ada humas gak mungkinlah, karena humas itu kan corong" (Wawancara, Yufita, 2010).

Munculnya kesan bahwa humas hanya sekedar corong semata. Kata corong yang memiliki konotasi negatif, karena corong bisa berarti cerobong yang menghasilkan suara yang nyaring, tidak beraturan dan menghasilkan asap gelap. Dengan ini dapat dimaknai bahwa informasi yang disampaikan nyaring tapi tidak sedap, maksudnya adalah tidak dapat dimengerti, dipahami untuk dilaksanakan.

Namun demikian narasumber penulis yang hampir $80 \%$ menyatakan bahwa pejabat humas pemerintah itu adalah corong menjelaskan bahwa corong disini bukan berarti yang berkonotasi negatif, melainkan mereka menjaga 
dan menciptakan masyarakat yang terinformasi.

Mereka menyadari bahwa humas tidak bisa asal bicara, tidak asal harus menyampaikan sesuatu, melainkan harus diciptakan sedemikian rupa, dan kemasannya harus bagus serta adaptable. Berikut adalah penyataan Kepala Biro Humas dan Hukum Kementerian PAN:

"Jangan bicara tentang corong, ini konotasinya kurang bagus, jadi kita ralat ya bukan corong tapi merupakan sarana untuk menyampaikan hasil kerja atau kinerja institusi kepada masyarakat, sampai sejauh mana masyarakat memahami, akan berdampak yang luas, artinya meningkatkan kesejahteraan".

Menanggapi pernyataan di atas, informan memberikan pesan pada praktisi humas pemerintah untuk memberikan informasi yang valid dan jelas. Hal ini seperti diungkapkan oleh Kepala Pusat Informasi dan Humas Kementerian Pendidikan Nasional:

"...jangan sampai informasi dikemas seperti kerupuk, maka terjadilah kebohongan publik".

Selain mengemas informasi yang sebenar-benarnya, humas pemerintah dalam menyebarkan informasi juga harus memperhatikan aspek emosional publik. Hal ini seperti diungkapkan oleh Kepala Pusat Informasi dan Humas Kementerian Pendidikan Nasional:

"...humas itu harus bekerja dengan hati, pada akhirnya akan memuaskan pelanggan, kemasannya harus bagus, adaptable".
Berdasarkan pernyataan tersebut, praktisi Humas harus melakukan segala fungsi pokoknya bukan hanya berdasarkan logika namun juga menggunakan perasaan. Jika hal tersebut tidak dilakukan akan berpotensi konflik baik di lingkup Pemerintah Daerah maupun pusat. Hal ini seperti diungkapkan oleh Teguh sebagai Kepala Sub Bidang Analisis Opini Publik Kementerian Komunikasi dan Informatika:

"Makanya, sering terjadi konflik antara pemerintah daerah dengan rakyatnya. Tentunya semua itu terjadi karena lemahnya atau bahkan tidak ada fungsi dan peran humas serta kurangnya informasi yang disampaikan pada publik atau pemilihan media yang kurang tepat, sehingga rakyat tidak faham".

Berdasarkan pernyataan tersebut, diketahui jika fungsi Humas sangat penting dalam mencegah konflik pada masyarakat selain itu, pentingnya pemilihan media dalam penyebaran informasi juga menjadi aspek yang perlu diperhatikan agar tidak terjadi misspersepsi di masyarakat.

Informan menyampaikan jika humas harus hati-hati dalam menyampaikan informasi baik dalam pemilihan media atau menyampaikannya langsung secara lisan pada publik. Hal serupa dijelaskan Kepala Sub Bidang Internal dan Eksternal Kementerian Komunikasi dan Informatika:

"Dalam penyampaian informasi kepada publik yaa menjawab baik-baik kalau tidak tahu langsung melempar kepimpinan. Penyampaian informasi juga lebih efektif disampaikan melalui media yang tepat". 
Dari pernyataan tersebut dapat bisa dikatakan bahwa, pejabat humas pemerintah sudah memahami bahwa istilah corong tidaklah tepat menjadi arti kata yang negatif. Karena maksud corong disini pejabat humas pemerintah menyuarakan, mensosialisasikan, dan menginformasikan segala kebijakan serta hasil kinerja dengan tidak asal bicara, melainkan menggunakan berbagai macam cara disesuaikan dengan siapa publiknya. Sehingga informasi yang disampaikan dapat tepat sasaran. Dalam perkembangannya pejabat humas pemerintah telah menyiapkan berbagai media selain media massa untuk menginformasikan kepada publik terkait dengan segala kebijakan dan hasil kinerja selama ini.

Prinsip yang dipegang teguh oleh pejabat humas pemerintahan adalah mereka berupaya untuk tidak melakukan kebohongan kepada publik, dengan cara mengemas informasi dengan jujur, terbuka, transparan, valid dan akuntable.

Sejarah awal munculnya public relations sudah ditekankan melalui bapak public relations Ivy Lee yang selalu mengedepankan fakta. Dia menambahkan bahwa publik harus kita hormati dengan memberikan informasi yang sebenarbenarnya.

Bermacam-macam cara telah digunakan oleh pejabat humas pemerintah untuk memberikan informasi kepada publik, mulai dari iklan, jumpa pers, pembuatan majalah dan buku, media online serta melaksanakan special event seperti pameran. Selain program tersebut, informan juga menyatakan jika humas harus mengoptimalkan media online dalam menjalankan fungsi pokok humas dalam menyebarkan informasi. Hal tersebut seperti dijelaskan oleh Kepala Biro Humas dan Hukum Kementerian PAN:

"Kita juga harus punya media on-line, kalau kita sudah punya, artinya disini pejabat humas juga harus memiliki kemampuan teknologi komunikasi informasi, wajib itu otomatis, itu mutlakitu, Itu kita menggali informasi, setiap saat, setiap detik di media online”.

Selain menggunakan media online, penting untuk melakukan press conference dalam menyebarkan informasi pada publik. Hal ini seperti diungkapkan oleh Kepala Biro Humas dan Hukum Kementerian PAN:

"Kemudian kita juga kalau ada kebijakan yang segera di informasikan untuk bisa membumi, mengadakan konferensi pers, itu kita mengundang para wartawan untuk hadir disini, kita menjelaskan apa yang menjadi informasi yang actual, yang harus disampaikan segera kepada masyarakat”.

Berdasarkan pernyataan di atas, kembali ditekankan jika informasi yang disampaikan pada publik harus akurat. Selain itu dijelaskan pula oleh informan jika humas pemerintah menjalan fungsi pokoknya melalui berbagai program seperti special events dan lainnya. Hal ini seperti diungkapkan oleh Kepala Biro 
Humas dan Hukum Kementerian PAN:

"Kita juga punya acara pameran, kita both yang bisa bongkar pasang, dan kita menerbitkan buku-buku apa yang menjadi sepak terjang kita sudah kita rangkum. Banyak buku-buku yang memberikan motivasi kepada aparatur dan masyarakat agar mereka bangkit, bangun dalam bekerja. Kita juga ada buku pelayanan publik, karna kita kan institusi yang melayani publik, artinya bagaimana melayani masyarakat yang efisien, efektif dan murah, macammacam lah ada pelayanan KTP dan SIM".

Menarik apabila mengupas satu-persatu, media-media yang dipergunakan oleh pejabat humas dalam menyampaikan informasi kepada publiknya. Sesungguhnya sangatlah beragam media-media komunikasi yang dapat digunakan oleh seorang pejabat humas, mulai dari komunikasi interpersonal, newsworthy dan iklan.

Dalam pemilihan media yang akan digunakan dalam menyebarkan informasi, sebaiknya lembaga melakukan analisis situasi yang merupakan salah satu bagian awal dari proses public relations. Analisis situasi berfungsi agar mengetahui situasi yang terjadi pada publik lembaga dan mengetahui langkah yang sebaiknya diambil dalam menyikapi kondisi tersebut (Cutlip, Center, \& Broom, 2009).

Data yang diperoleh melalui proses analisis situasi dapat dijadikan dasar dalam memilih media. Memang selama pengamatan penulis pada saat pengambilan data penulis melihat biro humas kementerian banyak menggunakan media bawah yaitu penggunaan X-banner di dalam lembaga pemerintahannya. Namun untuk menyampaikan informasi kepada publiknya humas pemerintah lebih sering melakukan jumpa pers, serta mempunyai ruangan khusus untuk teman-teman media atau wartawan mencari berita di lembaga Kementerian. Melihat realitanya humas pejabat kementerian memang sering berelasi dengan pers atau kawan-kawan media.

Media lain yang masih menjadi primadona adalah penggunaan iklan di media massa, baik media cetak maupun elektronik. Iklan memang memiliki jangkauan yang luas, namun iklan tidak cukup efektif untuk merubah pendapat, sikap dan tindakan publik-publik lembaga kementerian. Iklan hanya bersifat meneguhkan saja, tidak dapat merubah keputusan ataupun pendapat yang telah publik miliki.

Namun demikian pejabat humas juga masih memiliki 2 media lagi, yaitu komunikasi interpersonal dan media online. Komunikasi interpersonal telah banyak terbukti ampuh untuk merubah pendapat, sikap dan tindakan dari publik. Bicara komunikasi interpersonal sudah banyak berkembang, komunikasi interpersonal tidak hanya bicara face to face semata, melainkan dapat dilakukan dalam bentuk special event, maupun melalui media Internet. 
Tranformasi media dalam bentuk lain adalah mulai bermunculan media-media jejaring sosial seperti facebook dan twitter. Media tersebut terbukti ampuh untuk membentuk opini publik dalam mendapatkan dukungan. Mengingat lembaga pemerintah erat kaitannya dengan bidang politik, perlu dilakukan optimalisasi penggunaan media sosial dalam melakukan fungus Humas.

Berdasarkan hasil penelitian yang menjelaskan jika masyarakat bebas memberikan aspirasi, mengelola informasi bahkan menyebarkan informasi politik melalui media sosial sehingga kerap terjadi perebutan pesan politik dalam media sosial (Rusmulyadi \& Hafiar, 2018). Untuk itu, Humas Pemerintah harus mengontrol informasi dan memantau perkembangan penyebaran informasi utamanya di media sosial.

Penggunaan media online seperti mengkaktifkan media sosial juga website sebagai sarana yang mengoptimalkan fungsi pokok Humas Pemerintah sudah tepat. Seperti hasil penelitian yang mengemukakan bahwa salah satu pemerintah daerah berhasil menggunakan website dan media sosial untuk meninjau keadaan kota secara langsung dan dapat berinteraksi dengan masyarakat secara efektif (Ristanto, 2015). Masyarakat dapat menggunakan media internet secara efisien utamanya dalam penyampaian aspirasi.
Upaya lembaga pemerintah untuk menjalankan fungsinya dalam bentuk penyampaian informasi pada publik sudah sesuai. Seperti yang dijelaskan bahwa jika suatu lembaga pemerintah perlu menjalankan fungsi public relations dalam bentuk penyebaran informasi hal ini juga termasuk bentuk dari pelayanan publik yang dilakukan oleh lembaga Pemerintah melalui fungsi Humas (Djusan, 2013).

Fungsi PR yang diterapkan oleh lembaga Pemerintah dalam menyebarkan informasi sangat tepat. Berdasarkan Model Public relations yang dikemukakan oleh Grunig, Humas dapat berfungsi sebagai penyebar informasi dengan presentase ketepatan target marketnya sebesar 50\% (Djusan, 2013). Berikut adalah proses pelaksanaan fungsi pokok humas pemerintah dalam menyebarkan informasi mengenai kebijakan dan program pemerintah, pada tabel 1 .

Perbedaaan utama antara fungsi dan tugas Hubungan Masyarakat yang terdapat di instansi dinas pemerintah dan lembaga non pemerintah (perusahaan komersial swasta), yaitu tidak ada sesuatu yang diperjual belikan atau transaksi terjadi, baik berbentuk produk maupun jasa pelayanan yang ditawarkan kepada pihak membutuhkan komersial. Walaupun ada pihak humas pemerintah melakukan kegiatan kampanye publikasi, promosi pemasaran 
Table 1 Proses Pelaksanaan Fungsi Pokok Humas Pemerintah Dalam Menyebarkan Informasi Mengenai Kebijakan dan Program Pemerintah

\begin{tabular}{|c|c|c|c|c|}
\hline No & Tahapan & Bentuk & Upaya & Tujuan \\
\hline \multirow[t]{2}{*}{1} & $\begin{array}{l}\text { P e } n g \text { g a } 1 \text { i a } n \\
\text { informasi }\end{array}$ & Fact Finding & $\begin{array}{l}\text { Menggali informasi } \\
\text { dari internal dan } \\
\text { eksternal lembaga } \\
\text { (contohnya informasi } \\
\text { dari Deputi lain) }\end{array}$ & $\begin{array}{l}\text { Memperoleh informasi } \\
\text { secara mendalam dan } \\
\text { dapat disampaikan secara } \\
\text { jujur, terbuka, transparan, } \\
\text { valid dan akuntable pada } \\
\text { publik. }\end{array}$ \\
\hline & & Media Monitoring & $\begin{array}{l}\text { Klipping media } \\
\text { (media konvensional } \\
\text { atau online) }\end{array}$ & $\begin{array}{l}\text { - Untuk mengetahui } \\
\text { informasi tentang } \\
\text { peristiwa terkait dengan } \\
\text { lembaga. } \\
\text { - Untuk mengetahui opini } \\
\text { atau reaksi masyarakat } \\
\text { tentang kebijakan atau } \\
\text { program Pemerintah. }\end{array}$ \\
\hline 2 & $\begin{array}{l}\text { D i s t r i b u s i } \\
\text { Informasi }\end{array}$ & $\begin{array}{l}\text { Men y e barkan } \\
\text { informasi melalui } \\
\text { media }\end{array}$ & $\begin{array}{l}\text { - Penentuan media } \\
\text { berdasarkan hasil fact } \\
\text { finding } \\
\text { - Menjalin hubungan } \\
\text { baik dengan media } \\
\text { melalui } \\
\text { relations }\end{array}$ & $\begin{array}{l}\text { - M e n i } \mathrm{n} \mathrm{k} \mathrm{a} \mathrm{t} \mathrm{ka} \mathrm{n} \\
\text { kredibilitas lembaga } \\
\text { Pemerintah. } \\
\text { - Media berperan sebagai } \\
\text { sarana untuk publikasi } \\
\text { yang efektif. } \\
\text { diberikan Informasi yang } \\
\text { media dapat memenuhi } \\
\text { kebutuhan publik. }\end{array}$ \\
\hline
\end{tabular}

Sumber : Hasil Penelitian, 2010

dan periklanan, namun hal tersebut lebih menekankan kepada bentuk public services demi kepentingan pelayanan umum.

Fungsi humas pemerintah dalam melakukan pelayanan publik dijelaskan oleh Kepala Pusat Informasi dan Humas Kementerian Pendidikan Nasional:

"Ketiga public service terdiri dari konsep pelayanan ini, saya kira diyakini oleh humas-humas lain”.

Berdasarkan pernyataan di atas, sudah menjadi keharusan bagi humas pemerintah untuk menjalankan fungsi pokok humas dalam hal pelayanan masyarakat secara efektif karena sesuai dengan fungsi lembaga pemerintah yakni untuk memenuhi kebutuhan publik termasuk kebutuhan informasi. Sejalan dengan pernyataan tersebut, Kepala Sub Bidang Internal dan Eksternal Kementerian Komunikasi dan Informatika menyatakan bahwa:

"Humas pemerintahan menurut saya melayani masyarakat secara prima”.

Selain itu, keharusan lembaga pemerintah 
dalam melakukan pelayanan yang prima bagi masyarakat selain dikarenakan hakekat pemerintah sebagai pelayanan bagi masyarakat juga melihat hakekat masyarakat yakni masyarakat akan selalu menuntut pelayanan publik dengan kualitas yang baik dari lembaga Pemerintah (Kurniawan, 2016).

Dalam melakukan fungsi humas pemerintah yakni pelayanan publik, humas dituntut untuk cepat tanggap terhadap kebutuhan publik. Hal ini seperti diungkapkan oleh Kepala Bidang Hubungan Antar Lembaga Kementerian PAN: "Humas itu harus cepat, kita harus melayani orang seperti apa. Fungsi humas itu kan, layanan kan $y a$, baik melayani media, apa instansi-instansi lain apa LSM".

Keberadaan humas pemerintah di suatu lembaga atau instansi pemerintah tersebut merupakan keharusan, baik secara fungsional maupun operasional yang mampu bertindak sebagai public information, public affair dan public communication dalam upaya penyebarluasan atau mempublikasikan tentang kegiatan dan program kerja pembangunan pada instansi bersangkutan, baik ditujukan kepada publik internal maupun publik eksternal (masyarakat) pada umumnya.

Maka peranan humas pemerintah merupakan bagian dari saluran komunikasi instansi pemerintah, yaitu untuk memperlancar proses interaksi positif dan penyebarluasan informasi mengenai publikasi kebijakan dan hasil kinerja pemerintah melalui kerja sama dengan pihak media massa atau pers, baik menggunakan saluran media elektronik maupun media cetak lainnya, dan hingga menggunakan alat media komunikasi tradisional lainnya, seperti pementasan musik, wayang kulit atau wayang golek dan sebagainya untuk penyampaian pesan-pesan kebijakan dan keberhasilan kinerja pemerintah.

Sebagaimana telah dijelaskan sebelumnya, bahwa humas pemerintah sebagai sarana informasi juga sebagai supporting untuk membantu keberhasilan dalam melaksanakan program-program pemerintah, oleh karena itu harus memiliki kemampuan membangun hubungan yang positif, konsep kerja yang terencana baik dan hingga mampu menciptakan citra baik bagi lembaga yang diwakilinya, serta membangun opini publik yang positif.

Dalam melakukan fungsi pokok humas pemerintah, lembaga sebaiknya dapat lebih mengoptimalkan kemajuan teknologi Pernyataan ini berdasar pada salah satu hasil penelitian yang menunjukkan bahwa bahwa perkembangan teknologi dapat berdampak positifpadapelayananpublikyangdilakukanoleh lembaga pemerintah (Rahadi, 2007)yang terdiri dari 3 variabel utama, yaitu manfaat dirasakan (usefulness. Sejalan dengan pernyataan di atas, kemajuan teknologi khususnya pada akses 
informasi berdampak pada kualitas pelayanan Pemerintah dan persepsi masyarakat terhadap pelayanan lembaga Pemerintah (West, 2004).

Humas pemerintah sebagai jembatan, mediator atau fasilitator, ini merupakan salah satu fungsi ideal yang harus dijalankan oleh pejabat humas pemerintah. Tidaklah mudah ketika menjadi jembatan, bagaimana humas pemerintah dapat meski membangun jembatan yang mulus, penuh pesona sehingga publik akan percaya bahwa humas pemerintah layak dipercaya untuk menyelesaikan permasalahan yang dihadapi oleh publik. Jembatan ataupun fasilitator itu terbagi menjadi dua, yaitu fasilitator komunikasi dan fasilitator pemecahan masalah.

Bridiging, jembatan, maksudnya adalah menjembatani masyarakat yang tidak tahu menjadi tahu, masyarakat yang kekurangan informasi. Humas harus memiliki keteguhan, kepedulian, kecerdasan, dan kerja keras. Hal ini seperti diungkapkan oleh Kepala Pusat Informasi dan Humas Kementerian Pendidikan Nasional:

"...kalau jembatan bagus, maka masyarakat akan ikut menyebrang, atau bahkan hanya akan numpang lewat saja, tetapi ada juga yang menikmati "Selalu berpikir apa yang dimaui, dan memfasilitasi melalui dialogis dan negosiasi. Peraturan sebagai guide, penyampaiannya sadar atau tidak adalah hak masyarakat, karna itu kemas informasi agar sampai ke masyarakat, intinya mengemas kebijakan kepada masyarakat. Orang humas jangan pernah berpikir berapa lama dia di humas, tapi apa manfaat yang diberikan ketika dia menjadi humas".

Pernyataan di atas dapat diketahui jika fungsi pokok humas pemerintah sebagai jembatan antara publik dengan kepentingan lembaga merupakan hal yang sangat penting. Fasilitator komunikasi menjadikan humas pemerintah harus menjadi pendengar yang sensitif, ini dikarenakan fasilitator komunikasi berfungsi sebagai penghubung lembaga pemerintah dengan publiknya serta menjadi penerjemah apa yang belum dimengerti oleh publiknya.

Fungsi sebagai fasilitator komunikasi pernah dialami oleh pak Gatot Sugiharto ketika menangani demo guru-guru swasta berjumlah 3.000 orang, para guru swasta datang untuk menuntut agar bisa diangkat menjadi pegawai negeri. Demonstrasi ini terjadi akibat ketidaktahuan demonstran mengenai peraturan ataupun kebijakan Kementerian Pendayagunaan Aparatur Negara dan Reformasi Publik. Bapak Sugiharto sebagai kepala Biro Humas mengajak berdialog para demonstran dan menjelaskan bahwa guru swasta tidak bisa menjadi guru negeri, karena sudah di buat Undang-undangnya. Sedangkan untuk merubah dibutuhkan waktu yang panjang serta harus berdiskusi dengan Dewan Perwakilan Rakyat. Implementasi fungsi humas pemerintah sebagai jembatan publik dan lembaga dijelaskan oleh 
Kepala Bidang Hubungan Antar Lembaga

Kementerian PAN:

"... ini lho pak demo, aspirasinya gini-gini... misalnya dari pihak deputi kita gak bisa begitu, tapi kita yang nengahin... ini dari pihak kita, yang ini masyarakat. Tapi kita ,gak boleh marah-marah sama masyarakat. Kita harus merangkul masyarakat. Ya sudahlah kita kesini, tapi kita kan gak bisa masuk banyak".

Tindakan yang dilakukan oleh humas pemerintah beberapa lembaga sudah tepat. Karena pada prinsipnya, humas berperan sebagai fasilitator komunikasi, humas pemerintah melakukan fungsi sebagai penerjemah, penghubung dan juga mediator antara lembaga dan masyarakat (Dozier, Grunig, \& Grunig, 2013).

Peran humas pemerintah sebagai fasilitator komunikasi sangat berperan penting dalam penyampaian pesan agar komunikasi dapat berjalan efektif, untuk itu diperlukan komunikator yang meyakinkan (Ratnasari, Rahmat, \& Prastowo, 2018).

Humas pemerintah sebagai fasilitator komunikasi harus mengelola atau menciptakan komunikasi dua arah dan membuang gangguangangguan komunikasi serta tetap membuka saluran-saluran komunikasi. Komunikasi dua arah menjadi hal yang penting diperhatikan dalam pelaksanaan peran humas pemerintah. Melalui komunikasi dua arah, dapat menjadi media dalam melakukan evaluasi bagi penerapan kebijakan yang dilakukan lembaga pemerintah dan memperoleh feedback dari publik (Sani, Hidayat, \& Sjafirah, 2020).

Tujuan adalah agar menyediakan informasi yang memadai untuk organisasi dengan publiknya sehingga tercipta keuntungan bersama. Sebagai fasilitator komunikasi, humas pemerintah merupakan sumber informasi, sehingga humas pemerintah harus mengetahui seluruh kebijakan, seluruh informasi yang ada di lembaga atau organisasinya. Hal ini diperlukan agar tercipta komunikasi dua arah yang berkualitas.

Selain sebagai fasilitator komunikasi humas pemerintah juga sebagai fasilitator pemecah masalah. Hal ini dikarenakan fungsi humas pemerintah dapat membantu lembaga dalam menciptakan peluang ditengah aspirasi yang ditampung oleh humas melalui pelaksanaan fungsinya. Aspirasi diperoleh dari publik dan internal lembaga itu sendiri (Siswanto \& Abraham, 2016).

Fungsi humas sebagai fasilitator komunikasi juga di sadari betul oleh salah satu informan yakni Muhadjir bahwa humas pemerintah bukan hanya sebagai komunikator melainkan juga sebagai negosiator, negosiator untuk memecahkan permasalahan yang dihadapi organisasi dengan publiknya. Ketika menjalankan fungsi pemecah masalah, humas pemerintah harus bergabung dengan divisi- 
divisi lain dalam merencanakan rencanarencana strategis untuk menyelesaikan masalah.

Aspek yang penting diperhatikan dalam melakukan fungsi humas pemerintah sebagai jembatan publik dan lembaga adalah dengan melakukan komunikasi dua arah. Two Way Communication atau komunikasi dua arah itu adalah model komunikasi yang seharusnya diterapkan oleh pejabat humas pemerintah. Bagaimana pejabathumas pemerintah juga harus mendengarkan apa yang menjadi kebutuhan, keinginan dan ketertarikan publik pada masa ini. Kemampuan mendengar harus betul-betul mulai di asah oleh humas pemerintah, agar kebijakan yang nantinya di buat oleh pemerintah adalah kebijakan yang bermanfaat dan tidak Mubazir, maksudnya adalah kebijakan tersebut dapat diimplementasikan untuk kesejahteraan rakyat.

Disamping itu pula, konsep komunikasi persuasif dialogis untuk menyampaikan sosialisasi kebijakan sangatlah penting untuk menciptakan pencerahan kepada masyarakat. Masyarakat yang tercerahkan adalah masayarakat yang betul-betul mendapatkan informasi secara mendalam dan menyeluruh, bukan kulitnya saja. Mendalam dan menyeluruh ini pejabat humas pemerintah tidak sekedar menyampaikan isi dari kebijakannya, melainkan apa maksud dan tujuan itu dibuat, serta bagaimana menggunakan kebijakan tersebut sehingg kebijakan tersebut memiliki nilai guna yang tinggi.

Komunikasi dialogis ini bersifat persuasive, dimana dengan komunikasi persuasive dapat mempengaruhi pendapat, sikap dan tindakan dari masyarakat. Pendapat yang awalnya negatif tentang pemerintah ataupun kebijakan yang dikeluarkannya bisa berupa menjadi netral atau bahkan positif dengan komunikasi persuasive dengan menekan pada komunikasi secara interpersonal. Masyarakat yang tadinya belum mengetahui apa itu kebijakan pemerintah yang dimaksudkan menjadi mengetahui dan masyarakat menjadai tercerahkan dan akhirnya masyarakat dapat melakukan tindakan-tindakan yang tepat guna.

\section{SIMPULAN}

Penyebaran informasi pada publik diawali dengan adanya kesadaran bahwa humas merupakan garda terdepan pada lembaga pemerintah. Untuk itu, arus informasi harus dikuasai oleh praktisi humas pemerintah. Informasi yang diperoleh dari berbagai sumber harus dikemas sebagai informasi yang valid kemudian disebarkan pada publik. Tahapan teknis dalam melakukan fungsi pokok penyebaran informasi adalah: Pertama, menghimpun informasi baik dari internal maupun eksternal lembaga. Kedua, pelaksanaan monitoring melalui media monitoring. Melalui media monitoring akan terlihat isu apa yang 
sedang berkembang pada masyarakat sehingga untuk memenuhi informasi publik, humas lembaga dapat memilih media yang tepat. Media yang digunakan dalam penyebaran informasi sangat beragam. Peneliti menyarankan lembaga Pemerintah dapat mengoptimalkan kemajuan teknologi dalam mendukung pelaksanaan fungsi pokok humas pemerintah karena berdasarkan hasil penelitian, kemajuan media khususnya di bidang media online dapat meningkatkan partisipasi masyarakat pada kebijakan dan program pemerintah. Ketiga, membangun hubungan yang baik dengan media. Hal yang perlu diperhatikan oleh humas pemerintah dalam menjalankan fungsinya adalah bukan hanya memberikan informasi yang valid dan jelas pada publik, namun juga harus menyertakan perasaan pada penyampaian informasi sehingga akan timbul rasa peka terhadap isu tertentu.

Fungsi pelayanan publik merupakan kewajiban bagi lembaga pemerintah. Mengingat hakekat lembaga pemerintah dan masyarakat, dimana hakekat masyarakat akan menuntut lembaga pemerintah untuk memberikan pelayanan prima. Pelayanan publik dapat ditunjukan dengan sikap cepat tanggap lembaga pemerintah terhadap kebutuhan publik. Peneliti memberikan rekomendasi sebaiknya berbagai lembaga pemerintah mengoptimalkan kemajuan teknologi dalam pelaksanaan fungsi pelayanan publik karena dapat berdampak positif bagi kinerja lembaga juga kepuasan masyarakat pada lembaga pemerintah akan meningkat.

Fungsi pokok humas pemerintah dalam menjembatani kepentingan lembaga dan publiknya diwujudkan melalui peran sebagai fasilitator komunikasi. Humas Pemerintah sebagai fasilitator komunikasi harus mengelola atau menciptakan komunikasi dua arah dan membuang gangguan-gangguan komunikasi serta tetap membuka saluran-saluran komunikasi. Tujuan adalah agar menyediakan informasi yang memadai untuk organisasi dengan publiknya sehingga tercipta keuntungan bersama. Dalam melakukan fungsi sebagai fasilitator komunikasi penting diperhatikan agar Humas dapat menjalankan perannya bukan hanya sebagai komunikator namun juga sebagai negosiator. Hal yang perlu ditekankan dalam melakukan fungsi Humas ini adalah dengan menggunakan komunikasi dua arah pada setiap kegiatan komunikasi antara lembaga dengan publiknya.

\section{DAFTAR PUSTAKA}

Cutlip, S. M., Center, A. H., \& Broom, G. M. (2009). Effective public relations (10th ed.; E. Editions, Ed.). New Jersey: Prentice Hall Inc.

Djusan, A. (2013). Praktik government public relations paska otonomi daerah, sebuah tinjauan dengan kasus penyuluh $\mathrm{kb}$ sebagai government public relations 
bidang kb. Jurnal Studi Komunikasi Dan Media, 16(1), 61. https://doi.org/10.31445/ jskm.2012.160104

Dozier, D. M., Grunig, L. A., \& Grunig, J. E. (2013). Manager's guide to excellence in public relations and communication management. https://doi.org/https://doi. org/10.4324/9780203811818

Hong, H. (2013). Government websites and social media's influence on governmentpublic relationships. Public Relations Review, 39(4), 346-356. https://doi. org/10.1016/j.pubrev.2013.07.007

Kurniawan, R. C. (2016). Inovasi kualitas pelayanan publik pemerintah daerah. Jurnal Ilmu Hukum Fiat Justisia, 10(3). https:// doi.org/10.25041/fiatjustisia.v10no3.794

Kusumawati, D. (2008). Peran public relations dalam monitoring opini publik melalui media cetak maupun nasional di pt. pln (persero) area pelayanan dan jaringan Surakarta. Universitas Sebelas Maret.

Miles, M. B., Huberman, A. M., \& Saldana, J. (2014). Qualitative data analysis (3rd ed.; H. Salmon, Ed.). California: Arizona State University, USA.

Rahadi, D. D. R. (2007). Peranan teknologi informasi dalam peningkatan pelayanan di sektor publik. Seminar Nasional Teknologi 2007 (SNT 2007). https://doi.org/ISSN : $1978-9777$

Rahman, A., \& Sjoraida, D. F. (2017). Strategi komunikasi pemerintah kabupaten Subang menyosialisasikan gerakan pembangunan untuk rakyat infrastruktur berkelanjutan. Jurnal Kajian Komunikasi, 5(2), 136. https://doi.org/10.24198/jkk.v5i2.8443

Ratnasari, E., Rahmat, A., \& Prastowo, F. A. A. (2018). Peran humas perguruan tinggi negeri badan hukum dalam implementasi kebijakan keterbukaan informasi. PRofesi
Humas: Jurnal Ilmiah Ilmu Hubungan Masyarakat, 3(1), 21. https://doi. org/10.24198/prh.v3i1.14034

Ristanto, T.(2015). Peran humas pemerintah kota Balikpapan dalam mengimplementasikan konsep smartcitydiKotaBalikpapan.Jurnal Universitas Airlangga, 4(1), 387-399. Retrieved from http://journal.unair.ac.id/ COMN@peran-humas-pemerintah-kotabalikpapan-dalam-mengimplementasikankonsep-smart-city-di-kota-balikpapanarticle-9324-media-137-category-8.html

Ruslan, R. (2016). Manajemen public relations dan media komunikasi. Jakarta: Raja Grafindo Persada.

Rusmulyadi, R., \& Hafiar, H. (2018). Dekonstruksi citra politik Jokowi dalam media sosial. PRofesi Humas: Jurnal Ilmiah Ilmu Hubungan Masyarakat, 3(1), 120. https://doi.org/10.24198/prh. v3i1.16729

Sani, A., Hidayat, M., \& Sjafirah, N. A. (2020). Pemahaman petugas kehumasan kementerian dalam negeri tentang peran humas pemerintah. PRofesi Humas : Jurnal Ilmiah Ilmu Hubungan Masyarakat, 4(2), 215-236. https://doi.org/ISSN: 2541-3678 Saraswati, E. J., Romli, R., \& Nugraha, R. (2019). Kegiatan hubungan media pada direktorat komunikasi publik di universitas padjadjaran media relationships in public communication directorate. PRofesi Humas: Jurnal Ilmiah Ilmu Hubungan Masyarakat, 3(2), 202-218. https://doi.org/ ISSN: 2541-3678

Siswanto, B. D. L., \& Abraham, F. Z. (2016). Peran humas pemerintah sebagai fasilitator komunikasi pada biro humas Pemprov Kalimantan Selatan. Jurnal Penelitian Komunikasi. https://doi.org/10.20422/jpk. v19i1.64 
Waymer, D. (2013). Public relations review democracy and government public relations: expanding the scope of " relationship " in public relations research. Public Relations Review, 39(4), 320-331. https://doi.org/10.1016/j. pubrev.2013.07.015

West, D. M. (2004). E-Government and the transformation of service delivery and citizen attitudes. Public Administration Review, 64(1), 15-27. https://doi. org/10.1111/j.1540-6210.2004.00343.x 